Westinghouse Electric Sweden AB

\title{
SCWR - Safety Systems and Containment Investigations - Summary Report
}

Author, telephone

Nils-Olov Jonsson, +46 (0)21-34 7389

Dept

SE

Distribution

Order No

U. S. Department of Energy

A.107523

\section{ABSTRACT}

This report provides a listing of the reports and results generated by Westinghouse under the contract DE-FC07-03ID14465, “Generation IV Supercritical Water Reactor”. 


\section{Westinghouse}

\section{Report}

SE 04-069, rev 0

Page 2 of 5

\section{CONTENTS}

1. OVERVIEW OF TASKS

2. REVIEW OF DESIGN BASES AND REQUIREMENTS ON SAFETY SYSTEMS AND CONTAINMENT

3. GENERAL DESIGN CRITERIA AND SAFETY REQUIREMENT 3

4. CONTAINMENT DESIGN 3

5. DESIGN OF SAFETY SYSTEMS 3

6. REFERENCES 4 


\section{OVERVIEW OF TASKS}

The work results summarized in this report have been developed according to plans described in References [1] and [3].

Formal Progress Reports have been provided in References [4] through [12].

\section{REVIEW OF DESIGN BASES AND REQUIREMENTS ON SAFETY SYSTEMS AND CONTAINMENT}

This is reported in Reference [7]. The general design criteria and safety requirements are specified for the SCWR in order to provide a basis for the design of the safety systems and the containment. A combination of the most stringent requirements applied today is used. A key requirement that should be clarified further is the accommodation of core melt accidents in the safety requirements and the design criteria for the SCWR plant. On the basis of comparisons to modern BWR designs a number of possible safety system designs are identified and evaluated. The conclusion is that the major near term efforts should be put on the design of core cooling systems mitigating the effects of loss of core flow transients and loss of coolant accidents. The first layout of the containment is described. There is a major impact from the requirements put on mitigation of core melt accidents.

\section{GENERAL DESIGN CRITERIA AND SAFETY REQUIREMENT}

Design criteria and safety requirements were discussed in Reference [7]. A summary review of the design bases for a SCWR were provided in Reference [1].

\section{CONTAINMENT DESIGN}

The containment design was described in Reference [9]. The design bases were also provided in the report.

Calculations of the behaviour of the containment during accident conditions were provided in Reference [10]. These results have been further elaborated on in Reference [15]. The conclusion is that the containment design should not be an issue for the SCWR provided that sufficient space can be allowed for safety systems and passive behaviour of the containment.

\section{DESIGN OF SAFETY SYSTEM}

The design of the safety systems was discussed in Reference [7]. Specific designs were developed and documented in Reference [9]. 


\section{REFERENCES}

[1] Westinghouse proposal, “Technical Proposal for Generation IV Supercritical Water Reactor”

[2] Westinghouse STD-CM-546, “Award Number DE-FC07-03ID14465” (incl letter STD-CM544, which transmits DOE Form 24111.2, and letter STD-CM-545, which transmits the ACH Vendor / Miscellaneous Payment Enrollment Form)

[3] Westinghouse Memo SE 03-075

"SCWR - Phase 2 - Work Items \& Plan”

[4] SE 03-051, Letter June 26, 2003 to INEEL Jacopo Buongiorno

"SCWR Contract No. DE-FC07-03ID14465

Monthly Progress Report June 2003”

[5] SE 03-057, Letter August 11, 2003 to INEEL Jacopo Buongiorno

"SCWR Contract No. DE-FC07-03ID14465

Monthly Progress Report July 2003”

[6] SE 03-063, Rev 1, Letter September 8, 2003 to INEEL Jacopo Buongiorno

"SCWR Contract No. DE-FC07-03ID14465

Monthly Progress Report August 2003”

[7] Westinghouse Report SE 03-044, rev 1, January 7, 2004

"SCWR - Design Review and Design of Safety Systems and Containment - Status September, 2003"

[8] Westinghouse Letter SE 03-067, October 1, 2003 to INEEL Jacopo Buongiorno ”SCWR Contract No. DE-FC07-03ID14465 - Progress Report FY 2003”

[9] Westinghouse Report SE 04-001, January 7, 2004

"Generation IV Supercritical Water Reactor - Progress Report First Quarter of FY 2004”

[10] Westinghouse Letter STD-CM-594, “Cooperative Agreement DE-FC07-03ID14465. 3rd Quarterly Progress Report”. [January 1, 2004 through March 31, 2004].

[11] Westinghouse Letter STD-CM-612, “Cooperative Agreement DE-FC07-03ID14465. 4th Quarterly Progress Report”. [April 1, 2004 though June 30, 2004].

[12] Westinghouse Report SE 04-062, July 29, 2004

"Generation IV Supercritical Water Reactor - Progress Report Third Quarter of FY 2004” 


\section{Westinghouse}

\section{Report}

SE 04-069, rev 0

Page 5 of 5

[13] Westinghouse Memo SE 04-025, February 24, 2004

"SCWR - Work Plan for the Period February - March 2004"

[14] Westinghouse Report SE 03-396, August 13, 2003

"SCWR- Design Review- General Design Criteria and Safety Requirement"

[15] Westinghouse Memorandum SEP 04-404, July 23, 2004

"SCWR - Pressure and Temperature in the Reactor Containment During LOCA" 